\title{
INTEGRASI HARGA BERAS ERA PERDAGANGAN TERBUKA DAN DAMPAKNYA TERHADAP SWASEMBADA DAN KESEJAHTERAAN PELAKU EKONOMI BERAS
}

\section{Rice Price Integration in Open Trade Regime and Its Impact on Food Self- Sufficiency and Welfare}

\author{
Iwan Hermawan, Eka Budiyanti \\ Pusat Penelitian, Sekretariat Jenderal DPR RI \\ Gedung Nusantara 1, Lantai 2. JI. Jenderal Gatot Subroto, Jakarta, Indonesia 10270 \\ Email: eka.budiyanti@gmail.com
}

Naskah diterima: 29/07/2019; Naskah direvisi: 10/03/2020; Disetujui diterbitkan: 14/05/2020;

Dipublikasikan online: 15/07/2020

\begin{abstract}
Abstrak
Kebijakan liberalisasi perdagangan beras dianggap kurang populis dibandingkan progam pencapaian swasembada beras. Volatilitas harga beras dunia dikhawatirkan akan mengganggu kondisi perberasan nasional. Tujuan penelitian ini untuk menganalisis (a) integrasi harga beras domestik di tingkat pasar dunia dan pasar regional, dan (b) dampak integrasi harga beras terhadap swasembada dan kesejahteraan pelaku ekonomi beras. Pendekatan analisis yang digunakan adalah metode gabungan, yaitu (a) error correction model (ECM), (b) index of market connection (IMC), dan (c) model persamaan simultan. Data yang digunakan adalah data sekunder tahun 1998-2017. Hasil analisis menunjukkan harga beras domestik terintegrasi dengan harga beras dunia pada rezim perdagangan terbuka bebas (tahun 1998-1999) dan terbuka terkendali (tahun 2000-2007 dan tahun 20082017). Sementara di tingkat regional, harga beras di Jakarta dengan beberapa kota besar lainnya tidak terintegrasi. Meskipun demikian, melalui transmisi harga beras yang terbentuk menunjukkan adanya trade off antara peningkatan kesejahteraan produsen dan konsumen saat rezim pasar terbuka-bebas dibandingkan rezim pasar terbuka-terkendali. Hasil analisis yang sangat menarik adalah kebijakan pasar bebas ternyata lebih merangsang peningkatan kesejahteraan produsen daripada rezim pasar terbuka-terkendali. Tingkat swasembada beras yang menurun mengindikasikan terjadinya realokasi sumber daya. Oleh karena itu, kebijakan perdagangan bebas bukan harus dihindari, tetapi dapat menjadi opsi kebijakan untuk membantu memenuhi kebutuhan beras domestik.
\end{abstract}

Kata Kunci: Harga, Beras, Integrasi, Swasembada, Kesejahteraan, Rezim

\begin{abstract}
Trust through the rice world market was not considered as a populist option than the reach of rice self-sufficiency. Its volatility could negatively affect on domestic rice condition. This research analyzed (a) integration of domestic rice price at the world and regional market level, and (b) its impact on the rice self-sufficiency and the welfare of rice economic agents. The approach used joint methods, includes (a) error correction model (ECM), (b) index of market connection (IMC), and (c) simultaneous equations model. Secondary data was used in the period year 1998-2017. The result shows that domestic rice price is integrated with world rice price in open market regimes (the year 1998-1999) and open controlled market regimes (the year 2000-2007 and year 2008-2017). While at the regional level, rice prices in Jakarta with some of the big cities were relatively not integrated. Rice price transmission has revealed a trade-off between increasing producer's and consumer's welfare on free-market regimes compared with open under control regimes. Moreover, surprisingly, the free-market policy was more stimulating to increase producer's welfare than opened under the control regime. Rice self-sufficiency level decreasing represented resource reallocation. Hence, free trade rice policy is not a sin. It should be a potential option to help meet domestic rice needs.
\end{abstract}


Keywords: Price, Rice, Integration, Self-Sufficiency, Welfare, Regime

JEL Classification: C13, F13, F14

\section{PENDAHULUAN}

Menurut data Food and Agriculture Organization (FAO), harga beras Indonesia hingga awal tahun 2018 masih relatif lebih tinggi dibandingkan dengan rata-rata harga beras internasional. ${ }^{1}$ Bahkan Filipina dengan status perdagangan yang sama dengan Indonesia, memiliki harga beras yang relatif lebih rendah, yaitu USD 0,82 per kilogram dibandingkan Indonesia yang mencapai USD 1,01 per kilogram. Mahalnya harga beras tersebut disebabkan biaya produksi padi yang tinggi sebagai konsekuensi dari skala usaha padi yang kecil dan juga tingginya margin pemasaran beras (Idris, 2017). Hasil penelitian Azahari \& Hadiutomo (2014) pun mengklarifikasi apabila beras Indonesia pada dasarnya tidak memiliki daya saing di pasar internasional. Dawe (2008) memperkirakan Indonesia akan tetap berlanjut menjadi net importir beras karena kondisi geografis berkepulauan tanpa

Rata-rata harga beras Indonesia sebesar USD 1,01 per $\mathrm{kg}$ dengan kualitas medium (25\% patah). Harga beras internasionai (USD 0,40 per $\mathrm{kg}$ ) dihitung dari rata-rata harga beras di Thailand (USD 0,36 per kg), Vietnam (USD 0,36 per $\mathrm{kg}$ ), dan Myanmar (USD 0,49 per kg). (Sumber: http://www.fao.org/giews/foodprices/tool/public/\#/dataset/domestic). memiliki delta sungai dominan dan kontur tanah landai yang mendukung budidaya padi, seperti di Thailand dan Vietnam.

Dawe (2008) menjelaskan bahwa Indonesia sebenarnya dapat mempercayai pasar beras dunia guna mendukung pencapaian ketahanan pangan nasional melalui harga beras yang lebih stabil dan terjangkau. Dasar kepercayaan tersebut dapat dilihat dari pergerakan harga beras dunia yang cenderung semakin stabil dari tahun ke tahun. Namun demikian, opsi tersebut bukan kebijakan populis jika dibandingkan dengan kebijakan berswasembada beras bagi penguasa. Pro dan kontra impor beras sering menimbulkan "kegaduhan" di masyarakat, meskipun besarnya tidak lebih dari $2 \%-3 \%$ dari total produksi beras nasional. Selain itu, pro dan kontra terhadap kebijakan impor beras tersebut juga terjadi pada tataran aktor pemerintah yang membawa kepentingannya masing-masing (Kusumah, 2019).

Rezim pemerintahan dari Orde Lama hingga era reformasi berusaha mencapai swasembada beras dengan 
berbagai kebijakan perberasan, baik dengan mengisolasi pasar beras domestik maupun dengan mulai membuka pasar beras domestik dengan pasar beras internasional seiring bergulirnya momentum liberalisasi perdagangan. Kondisi ini tentu akan berimplikasi besar terhadap perkembangan harga beras di dalam negeri, termasuk pula memengaruhi perilaku produsen dan konsumen beras.

Konsep integrasi pasar semakin banyak diperbincangkan ketika rezim perdagangan bebas beras yang ditetapkan oleh pemerintah mulai diberlakukan. Ketika rezim kebijakan pasar bebas diganti dengan kebijakan pasar bebas terkendali, harga beras Indonesia justru terdispersi lebih tinggi dan berfluktuasi dibandingkan rata-rata harga beras dunia. Menariknya pada periode rezim isolasi pasar menunjukkan perkembangan harga beras domestik yang lebih stabil dibandingkan rezim pasar bebas dan pasar bebas terkendali. Lantas apakah kebijakan pasar bebas terkendali tersebut perlu dievaluasi kembali, termasuk contohnya permintaan Indonesia menangguhkan tarif beras dalam skema ASEAN Trade in Goods Agreement (ATIGA) apakah sudah tepat? Penelitian yang berkaitan dengan integrasi pasar beras Indonesia, baik pada level nasional, regional, maupun internasional sejatinya telah banyak dilakukan. Contohnya Sugiyanto \& Hadiwigeno (2018); Makbul \& Ratnaningtyas (2017); Hidayanto, et al. (2014); Varela, et al. (2012); Widadie \& Sutanto (2012), Marks (2010); Kustiari \& Suhaeti (1998); dan Alexander \& Wyeth (1994).

Sugiyanto \& Hadiwigeno (2018) menganalisis keterkaitan pasar beras domestik dengan pasar internasional melalui Vector Error Correction Model (VECM). Hasilnya menunjukkan bahwa pasar beras terintegrasi, baik di dalam negeri maupun dengan luar negeri, sehingga setiap fluktuasi di kedua pasar akan saling berpengaruh. Data yang digunakan berupa data bulanan dari tahun 2000-2010 dan harga beras Indonesia berupa harga beras medium, sedangkan harga beras dunia berupa harga beras Thailand A1 super. Hidayanto, et al. (2014) dengan menggunakan data mingguan dari tahun 2010-2012 yang dianalisis melalui VECM dan Model Persamaan Regresi, menunjukkan hasil yang sama pula. Pasar beras grosir di Pasar Induk Beras Cipinang (PIBC) dengan harga beras internasional memperlihatkan 
kointegrasi, khususnya antara harga beras jenis IR-64 kualitas II dengan harga beras internasional Thailand broken $15 \%$ dan Vietnam broken $15 \%$. Sedangkan Widadie \& Sutanto (2012) dengan menggunakan metode gabungan, yaitu VECM dan two stage least squares (2SLS), juga menghasilkan simpulan yang sama bahwa terdapat kointegrasi antara harga beras domestik dengan harga beras internasional. Namun demikian, berbeda dengan hasil penelitian Bustaman (2003), di mana pasar beras domestik ternyata terintegrasi lemah dengan pasar beras internasional.

Makbul \& Ratnaningtyas (2017) dan Kusumaningsih, et al. (2016) mencoba mengukur integrasi harga beras dan harga padi. Mereka menganalisis data menggunakan VECM. Hasilnya menunjukkan harga beras terintegrasi dengan harga padi dan terdapat hubungan dalam jangka pendek dan jangka panjang.

Varela, et al. (2012) melakukan penelitian untuk mengetahui faktorfaktor determinan dari perbedaan harga dan integrasi pasar antar provinsi di Indonesia. Metode yang digunakan adalah analisis regresi untuk menentukan faktor penentu perbedaan harga dan integrasi pasar. Hasilnya menunjukkan adanya integrasi pasar yang besar dan perbedaan harga yang kecil untuk komoditas beras dan gula, yaitu sekitar 5\%-12\%. Sedangkan untuk komoditas jagung, kedelai, dan minyak goreng, terdapat integrasi pasar yang kecil dan perbedaan harga yang lebih tinggi (16\%-22\%). Sedangkan Hidayanto, et al. (2014) menambahkan secara khusus bahwa faktor-faktor yang memengaruhi integrasi pasar beras antar provinsi di Indonesia adalah infrastruktur transportasi, pendapatan per kapita, aktivitas pembelian (pengadaan) beras petani oleh Perum Badan Urusan Logistik (Bulog) dan penyaluran beras untuk keluarga miskin (Raskin).

Marks (2010) mencoba membuktikan secara kuantitatif lambatnya proses integrasi ekonomi secara nasional di Indonesia. Dalam hal ini, Marks melakukan secara spesifik pada pasar beras. Hasilnya menunjukkan bahwa sepanjang masa kolonial, pasar beras Indonesia terintegrasi dengan baik dan berjalan sangat efektif. Namun, pada saat perang dunia kedua dan masa perjuangan kemerdekaan, terjadi disintegrasi dan inefisiensi pasar.

Dengan menggunakan uji kointegrasi, Kustiari \& Suhaeti (1998) 
mencoba melihat integrasi pasar beras di Indonesia. Hasilnya bahwa tidak semua pasar yang letaknya berdekatan berintegrasi satu sama lain, hanya terdapat 26 kombinasi pasar yang berkointegrasi. Simpulan dari penelitian ini adalah Perum Bulog sebagai pengontrol harga tidak dapat mencegah terjadinya segmentasi pasar. Senada dengan itu, hasil penelitian dari Sari (2010) menjelaskan bahwa pasar beras di 12 kota besar di Indonesia juga tidak terintegrasi secara penuh. Sedangkan Alexander \& Wyeth (1994) mencoba mengaplikasikan error correction mechanism (ECM) dengan Model Ravallion untuk menguji kointegrasi spasial pasar beras di tujuh kota wilayah Indonesia. Hasil penelitian menunjukkan bahwa harga beras di semua pasar terintegrasi dengan IHK meskipun tidak selalu ada kausalitas antara harga beras di suatu wilayah dengan wilayah lainnya.

Berbagai hasil penelitian tersebut beragam karena adanya perbedaan dari periode analisis, proksi harga beras, jenis beras, dan pendekatan yang digunakan. Bahkan di antaranya mencoba menggabungkan beberapa pendekatan untuk mengelaborasi isu kointegrasi beras secara komprehensif. Namun demikian, ada bagian yang masih luput dianalisis, yaitu berkenaan dengan rezim tata kelola perdagangan perberasan nasional dan refleksinya terhadap upaya pemerintah mewujudkan program swasembada beras dan peningkatan kesejahteraan pelaku ekonomi beras.

Berdasarkan penjelasan tersebut, tujuan penelitian ini adalah menganalisis (a) integrasi harga beras Indonesia pada pasar internasional di berbagai periode rezim perdagangan terbuka-bebas dan (b) dampak rezim perdagangan terbuka-bebas terhadap swasembada beras dan kesejahteraan pelaku ekonomi beras, baik produsen maupun konsumen beras. Hal ini penting untuk dianalisis agar refleksi kebijakan perdagangan beras dapat mendukung ketahanan pangan domestik, mengingat harga adalah sinyal penting para pelaku ekonomi dalam merealokasi sumber daya.

Berdasarkan dari perspektif teori perdagangan internasional, sejatinya perdagangan akan membuat masingmasing pelakunya menjadi better off. Hal ini distimulasi dari sinyal harga sehingga akan mendorong proses alokasi sumber daya yang lebih efisien dibandingkan autarky. Pasar yang lebih terbuka atau momentum liberalisasi perdagangan menjadikan seluruh 
pelaku ekonomi yang terlibat mencapai keseimbangan yang optimal. Namun sayangnya, dalam kaitannya dengan pangan (termasuk beras), perspektif teori tersebut tidak serta merta menjadi dasar pengambilan kebijakan karena berbagai pertimbangan, termasuk asumsi-asumsi ketat yang membangun teori perdagangan internasional dibandingkan dengan kenyataan di lapangan. Oleh sebab itu, menurut FAO (2003) suatu negara akan dihadapkan pada dua pilihan strategi pangan terkait liberalisasi perdagangan, yaitu food self-sufficiency atau food self-reliance. Masing-masing strategi tersebut berimplikasi besar terhadap tata kelola sektor pangan di suatu negara, kawasan, dan bahkan dunia.

Liberalisasi perdagangan beras yang ditandai dengan berkurangnya hambatan perdagangan (termasuk tarif impor), dapat mendorong terjadinya integrasi antara dua pasar atau lebih. Integrasi yang terjadi dapat berupa integrasi harga dan integrasi pasar. Adapun integrasi harga merujuk pada terjadinya transmisi harga dari suatu pasar ke harga di pasar lainnya, baik secara vertikal maupun horizontal. Sedangkan integrasi pasar melihat hubungan antara dua pasar atau lebih, baik spasial (Ravallion, 1986) maupun vertikal.

\section{METODE}

Untuk menjawab tujuan penelitian ini maka digunakan gabungan pendekatan sebagai upaya menganalisisnya secara komprehensif, yaitu (1) Error Correction Model (ECM), (2) Index of Market Connection (IMC), dan (3) Simultaneous Equations Model (SEM). Konstruksi gabungan pendekatan tersebut membutuhkan data time series berbagai periode tahun. Untuk pendekatan ECM dan IMC digunakan data harga per bulan selama rentang tahun 1998-2017, baik harga beras Indonesia maupun harga beras Thailand (sebagai harga beras acuan). Jenis beras yang diperdagangkan adalah beras jenis Indica dengan kualitas medium (pecah $20 \%-25 \%$ ) yang banyak dikonsumsi oleh masyarakat di Asia Tenggara. Sedangkan untuk mendukung pendekatan persamaan simultan digunakan data tahunan periode tahun 1992-2016. Seluruh data yang digunakan bersumber dari Badan Pusat Statistik (BPS), Badan Perencanaan Pembangunan Nasional (Bappenas), Kementerian Perdagangan, FAO, Kementerian Pertanian, World Bank, United States Department of 
Agriculture (USDA), International Monetary Fund (IMF), International Rice Research Institute (IRRI), dan sumber terpercaya lainnya. Seluruh data dalam nilai, termasuk harga, dikoreksi dengan menghilangkan efek inflasinya (disebut sebagai data riil). Tekniknya dilakukan dengan menggunakan Indeks Harga Konsumen pada tahun dasar tahun 2010.

Model pertama adalah ECM, yang bertujuan untuk menganalisis integrasi vertikal pasar beras. Prosedurnya mencakup (1) uji akar unit Dickey Fuller untuk melihat stasionaritas data time series sebelum dilakukan uji lainnya, (2) uji kointegrasi dengan pendekatan uji Johansen. Metode ini mensyaratkan melakukan dua uji statistik lainnya, yaitu uji Trace (Trace test, $\lambda$ trace) dan uji maximum eigenvalue ( $\lambda$ maks), dan (3) uji Granger Causality untuk melihat hubungan dua arah dari variabel harga beras Indonesia dan harga beras internasional. Proses running data untuk ECM menggunakan Eviews 9.
Selanjutnya dihitung IMC sebagai pendekatan kedua, sesuai periode rezim yang dikembangkan oleh OECD (OECD, 2013: 74). ${ }^{2}$ Pendekatan ini sudah banyak dilakukan oleh para peneliti, seperti Agung \& Daryanto (2017), Carolina, et al. (2016), Layade \& Adeoye (2014), Arnanto, et al. (2014), dan Akintunde, et al. (2012). Tujuan aplikasi IMC adalah untuk melihat dampak harga beras internasional terhadap harga beras Indonesia (sesuai hasil kausalitas metode pertama) dalam jangka pendek dan menganalisis integrasi spasial sederhana antara pasar beras di Jakarta dengan kota-kota besar lainnya. Nilai IMC berbentuk rasio, yaitu antara $0 \leq \mathrm{IMC} \leq \infty$. Jika nilainya semakin mendekati nol maka harga beras domestik terintegrasi kuat dalam jangka pendek dan terintegrasi lemah jika nilai IMC lebih besar 1 (makin besar).

\footnotetext{
$\mathbb{P}_{1 t}=\alpha_{0}+\beta_{1} P_{1(t-1)}+\beta_{2}\left(P_{w(t)}-P_{w(t-1)}\right)+\beta_{a} P_{w(t-1)}+\varepsilon_{t}$ . $\mathrm{Pi}(\mathrm{t})$ adalah harga beras Indonesia tahun $t, \mathrm{Pw}(\mathrm{t})$ adalah harga beras di pasar internasional tahun $t$, $\mathrm{Pi}(\mathrm{t}-1)$ adalah harga beras Indonesia tahun $t-1$, Pw(t1) adalah harga beras di pasar internasional tahun $t$ $1, \varepsilon$ adalah error term, $\alpha_{0}$ adalah konstanta, dan $\beta_{1-3}$ adalah koefisien parameter.
} 


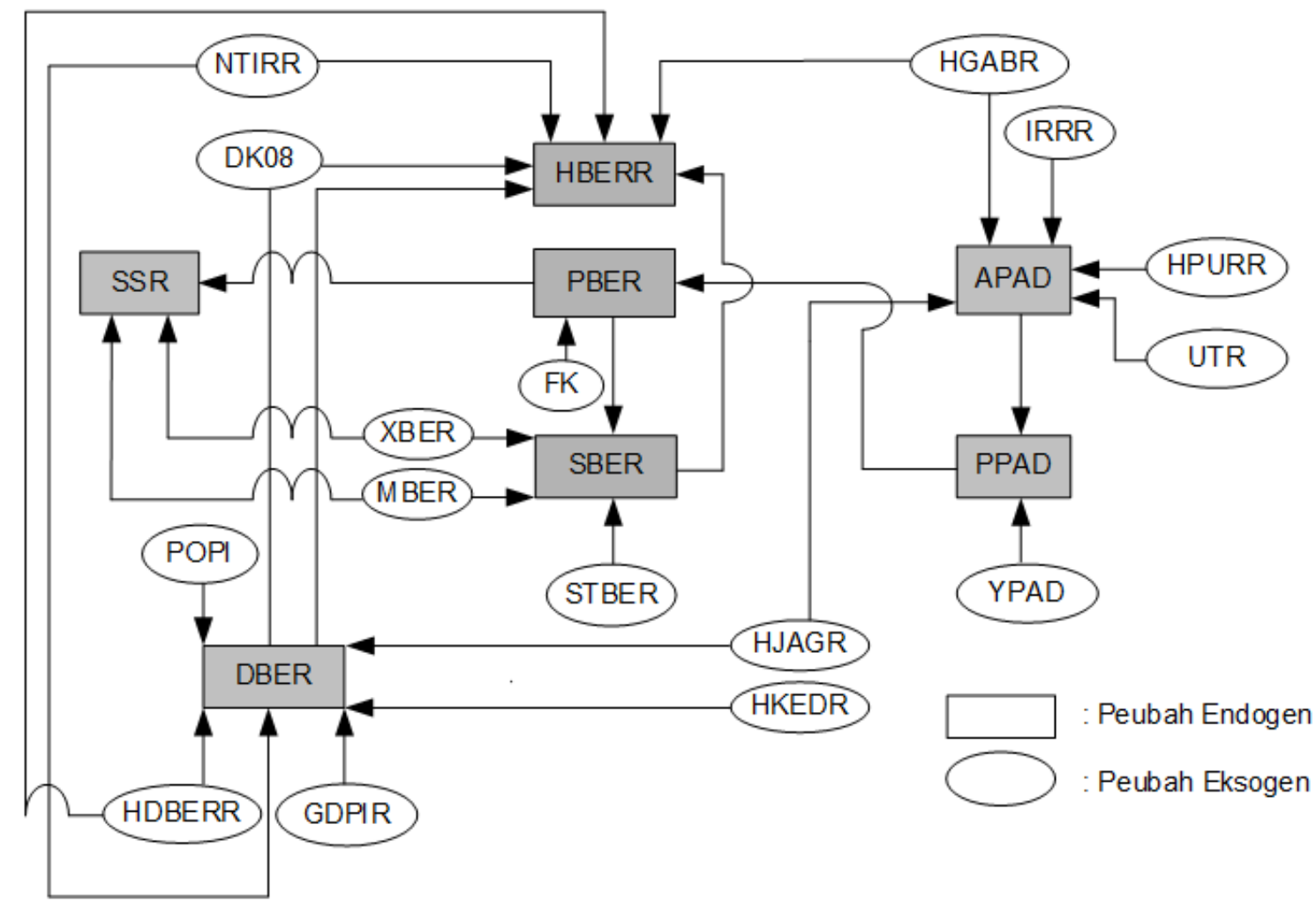

\section{Gambar 1. Model Ekonomi Beras Indonesia}

Sumber: Penulis (2018)

Hasil dari IMC tersebut kemudian diinjeksi secara top down ke dalam model analisis ketiga, yaitu persamaan simultan dengan simulasi ex-post sesuai periode rezim perdagangan. Model persamaan ini dibangun dari banyak persamaan, seperti produksi, permintaan, harga, penawaran, dan lainnya. Keterhubungan antara variabel endogen dan eksogen mengacu pada teori ekonomi dan hasil empiris. Detail grafis persamaan simultan disajikan pada Gambar 1.
Adapun seluruh persamaan, baik struktural maupun identitas, yang digunakan dalam penelitian ini, termasuk hipotesis yang menyertainya, disajikan sebagai sebagai berikut:

a. Persamaan areal panen padi

$$
\begin{aligned}
& A P A D_{t}=a_{0}+a_{1} H_{B E R R} t_{t-1}+a_{2} H_{G A B R}-1+ \\
& \mathrm{a}_{3} \mathrm{HJAGR}_{\mathrm{t}-1}+\mathrm{a}_{4} \mathrm{HPURR}_{\mathrm{t}-1}+ \\
& a_{5} U T R_{t-1}+a_{6} / R R R+a_{7} T+ \\
& \text { as } A P A D_{t-1}
\end{aligned}
$$

Tanda dugaan parameter yang diharapkan adalah $a_{1}, a_{2}, a_{7}>0$; $a_{3}, a_{4}, a_{5}, a_{6}<0$; dan $0<a_{8}<1$. 
b. Persamaan permintaan beras DBER $_{t}=b_{0}+b_{1}$ HBERR $_{t-1}+b_{2}$ HJAGR $_{t}+$ $\mathrm{b}_{3} \mathrm{HKEDR}_{\mathrm{t}}+\mathrm{b}_{4}\left(\right.$ GDPIR $_{\mathrm{t}} /$ POPI $\left._{\mathrm{t}}\right)+$ $b_{5} T+b_{6} D_{K 08}+b_{7} D_{B E R}$

Tanda dugaan parameter yang diharapkan adalah $b_{1}, b_{2}, b_{4}, b_{5}>0$; $b_{3}, b_{6}<0$; dan $0<b_{7}<1$.

c. Persamaan harga beras domestik

$$
\begin{aligned}
\text { HBERR }_{t}= & \mathrm{c}_{0}+\mathrm{c}_{1}\left(\text { HDBERR }_{\mathrm{t}}{ }^{*} \text { NTIRR }_{\mathrm{t}}\right)+ \\
& \mathrm{c}_{2} \mathrm{HGABR}_{\mathrm{t}}+\mathrm{c}_{3}\left(\text { DBER }_{\mathrm{t}}-\mathrm{DBER}_{\mathrm{t}-1}\right) \\
& +\mathrm{c}_{4}\left(\text { SBERR }_{\mathrm{t}}-\text {SBER }_{\mathrm{t}-1}\right)+\mathrm{c}_{5} \mathrm{~T}+ \\
& \mathrm{c}_{6} \mathrm{DKO}+\mathrm{c}_{7} \mathrm{HBERR}_{\mathrm{t}-1} \ldots \ldots \ldots . .(3)
\end{aligned}
$$

Tanda dugaan parameter yang diharapkan adalah $\mathrm{C}_{1}, \mathrm{C}_{2}, \mathrm{C}_{3}, \mathrm{C}_{5}, \mathrm{C}_{6}>$ 0 ; $\mathrm{c}_{4}<0$; dan $0<\mathrm{c}_{7}<1$.

d. Persamaan produksi beras

$$
\mathrm{PBER}_{\mathrm{t}}=\mathrm{PPAD}_{\mathrm{t}}{ }^{\star} \mathrm{FK}
$$

e. Persamaan penawaran beras

$$
\begin{aligned}
\text { SBER }_{t}= & \text { PBER }_{t}-X \text { XER }_{t}+\text { MBER }_{t}+ \\
& \text { STBER } R_{t-1} \ldots \ldots \ldots \ldots \ldots \ldots \ldots
\end{aligned}
$$

f. Persamaan produksi padi

$$
\text { PPAD }_{\mathrm{t}}=\text { APAD }_{\mathrm{t}}{ }^{*} \mathrm{YPAD}_{\mathrm{t}}
$$

g. Persamaan indeks swasembada beras

$$
\begin{aligned}
\text { SSR }_{t}= & \left(\text { PBER }_{t} /\left(\text { PBER }_{t}+\text { MBER }_{t}\right.\right. \\
& \text { XBER } \left.\left._{t}\right)\right)^{*} 100 \ldots \ldots \ldots \ldots \ldots . .(7)
\end{aligned}
$$

Detail seluruh variabel dan singkatan variabel yang digunakan di dalam penelitian ini, baik yang tersaji pada Gambar 1 dan pada seluruh persamaan simultan dijelaskan lebih lanjut pada Tabel 1. Tanda $t$ menunjukkan tahun ke- $t$ dan tanda $t-1$ menunjukkan tahun $t-1$. Simbol $a, b$, dan $c$ menunjukkan konstanta dan dugaan parameter. Seluruh data dalam nilai, termasuk harga, menggunakan data riil dengan tahun dasar tahun 2010.

\section{Tabel 1. Variabel dan Keterangan Variabel yang Digunakan dalam Penelitian}

\begin{tabular}{cll}
\hline No. & Variabel & \multicolumn{1}{c}{ Keterangan } \\
\hline 1. & PBER & Produksi beras \\
2. & APAD & Luas panen lahan padi \\
3. & PPAD & Produksi Padi \\
4. & SBER & Penawaran beras \\
5. & DBER & Permintaan beras \\
6. & HBERR & Harga beras \\
7. & HGABR & Harga padi \\
8. & HPURR & Harga pupuk \\
9. & HJAGR & Harga jagung \\
10. & HKEDR & Harga kedelai \\
11. & HDBERR & Harga beras dunia \\
12. & YPAD & Produktivitas padi \\
13. & STBER & Stok beras \\
14. & FK & Faktor konversi padi ke \\
15. & T & beras \\
16. & XBER & Tren waktu \\
17. & MBER & Impor beras beras \\
18. & GDPIR & PDB Indonesi \\
19. & NTIRR & Nilai tukar Rp/USD \\
20. & POPI & Jumlah penduduk \\
21. & DK08 & Dummy krisis pangan \\
22. & UTR & tahun 2008 \\
23. & IRRR & Upah tenaga kerja \\
24. & SSR & Singkat suku bunga \\
\hline
\end{tabular}

Model persamaan simultan yang dirumuskan tersebut memiliki tujuh persamaan (G) yang terdiri dari tiga persamaan struktural dan empat persamaan identitas. Sementara itu, terdapat 19 peubah predetermined variables yang terdiri dari 16 peubah 
eksogen dan tiga lag endogenous variables sehingga total peubah dalam model $(\mathrm{K})$ adalah tujuh ditambah 19 maka sama dengan 26 peubah. Jumlah peubah terbanyak pada persamaan (M) adalah delapan peubah. Berdasarkan kriteria order condition, setiap persamaan struktural yang ada dalam model adalah over identified.

Untuk identifikasi persamaan menggunakan order condition, metode pendugaan parameternya menggunakan 2SLS, peramalan variabel eksogen menggunakan metode Stepar dan prosedur Forecast, serta peramalan variabel endogen menggunakan metode Newton dengan prosedur Simnlin. Kriteria statistik validasi pendugaan model menggunakan Root Means Square Error (RMSE), Root Means Square Percent Error (RMSPE), dan Theil's Inequality Coefficient (U-theil). Seluruh proses running data IMC dan persamaan simultan dijalankan dengan program Statistical Analysis System (SAS) versi 9,2.

Lebih lanjut untuk melihat dampak integrasi harga hingga pada perubahan kesejahteraan pelaku ekonomi beras maka digunakan pendekatan surplus ekonomi, baik surplus produsen dan surplus konsumen beras. Surplus konsumen beras merupakan kelebihan dari kepuasan total (dinilai dengan uang) yang dinikmati konsumen karena mengkonsumsi sejumlah beras dibandingkan pengorbanan totalnya (dinilai dengan uang). Sedangkan surplus produsen beras merupakan kepuasan total yang didapat produsen dari selisih hasil yang didapat dengan biaya yang dikeluarkannya lebih kecil. Secara sistematis, surplus konsumen dan produsen beras diukur dengan mengintegralkan fungsi penawaran dan fungsi permintaan (Chiang, 1984):

$C S=\int^{P d d_{P e} Q d(P) d p}$

$P S=\int e^{P m Q s}(P) d p$.

Di mana Qs merupakan fungsi penawaran, Qd merupakan fungsi permintaan, CS merupakan surplus konsumen, PS merupakan surplus produsen, $\mathrm{Pe}$ merupakan harga keseimbangan, $\mathrm{Pd}$ merupakan harga pada perpotongan kurva permintaan, dan $\mathrm{Pm}$ merupakan harga pada perpotongan kurva penawaran.

Untuk memudahkan perhitungan maka formula CS dan PS dihitung dengan mengasumsikan kurva permintaan dan penawarannya berbentuk linier. Implikasinya adalah nilai CS dan PS dapat dihitung dengan menggunakan formula luas segitiga. Bentuk kedua kurva akan tergantung 
pada besaran elastisitasnya yang diperoleh dari hasil estimasi persamaan simultan. Daerah segitiga dari perpotongan antara kurva permintaan dan penawaran pada harga tertentu sebelum ada kebijakan disimbolkan dengan $b$ (base value) dan setelah adanya kebijakan disimbolkan dengan $s$ (simulation result).

Untuk surplus atau penerimaan pemerintah tidak dihitung dalam penelitian ini. Perubahan surplus ekonomi dihitung dengan formula sebagai berikut:

$\triangle S P B=\operatorname{SBER}_{t}{ }_{t}\left(H_{B E R^{s}}{ }_{t}-H B E R_{t}^{b}\right)+1 / 2$ $\left(\right.$ SBER $_{t}{ }_{t}-S$ SER $\left._{t}{ }_{t}\right)\left(\right.$ HBER $_{t}{ }-$ $\mathrm{HBER}_{\mathrm{t}}^{\mathrm{b}}$ )

$\Delta S K B=$ DBER $_{t}^{\mathrm{s}}\left(\mathrm{HBER}_{\mathrm{t}}^{\mathrm{b}}-\mathrm{HBER}_{\mathrm{t}}^{\mathrm{s}}\right)+1 / 2$

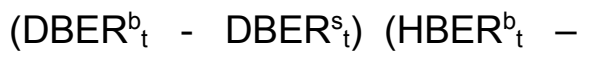
$\operatorname{HBER}_{\mathrm{t}}^{\mathrm{s}}$ )

dimana, $\triangle$ SPB adalah surplus produsen beras, $\triangle \mathrm{SKB}$ adalah surplus konsumen beras, $b$ adalah nilai dasar sebelum ada simulasi, dan $s$ adalah nilai simulasi kebijakan.

Pada bagian simulasi, periode simulasi disesuaikan dengan dua periode rezim perdagangan, yaitu (1) rezim perdagangan terbuka-bebas pada tahun 1998-1999 dan (2) rezim perdagangan terbuka-terkendali pada tahun 2000-2007, 2008-2017, dan tahun 2000-2017. Rezim perdagangan terbuka-bebas ditandai dengan liberalisasi sektor perberasan, memprivatiasi Bulog, dan menghapus hambatan perdagangan (Ardiyanto, 2012). Sedangkan era perdagangan terbuka-terkendali ditandai dengan pengenaan tarif atau bea masuk beras hingga saat ini sebagai bentuk terbuka namun terkendali. Pada awal tahun 2000 terdapat Keputusan Menteri Keuangan No. 568/KMK.01/1999 tentang Penetapan Tarif Bea Masuk Atas Impor Beras dan Gula, di mana bea masuk beras sebesar Rp 430 per kilogram. Bahkan pada tahun 2017 berdasarkan Peraturan Menteri Keuangan No. 6/PMK.010/2017 tentang Penetapan Sistem Klasifikasi Barang dan Pembebanan Tarif Bea Masuk Atas Barang Impor, bea masuk beras ditetapkan sebesar Rp 450 per kilogram. Selain itu, peran Bulog mulai dioptimalkan melalui kebijakan fleksibilitas harga pembelian bagi Bulog melalui Inpres No. 8 Tahun 2011 tentang Kebijakan Pengamanan Cadangan Beras yang Dikelola oleh Pemerintah dalam Menghadapi Kondisi Iklim Ekstrim dan kemudian diperbaharui dengan Instruksi Presiden No. 3 Tahun 2012 tentang Kebijakan Pengadaan Gabah/Beras dan Penyaluran Beras oleh Pemerintah 
(Farid, et al., 2014: 15). Lebih lanjut, pembagian periode tahun 2008-2017 dan tahun 2000-2017, meskipun samasama dalam rezim perdagangan terbuka-terkendali, sebagai bagian memperdalam analisis ketika terjadi krisis pangan dunia pada tahun 2008.

HASIL DAN PEMBAHASAN

\section{Perkembangan Ekonomi Beras} Indonesia

Perkembangan volatilitas ekonomi perberasan nasional tidak dapat dilepaskan dari rezim pemerintahan yang sedang berkuasa. Pada rezim pemerintahan Soekarno hingga saat ini sekalipun, perkembangan ekonomi beras Indonesia masih sangat dinamis. Dua kebijakan yang selalu hadir dan cenderung membawa polemik adalah kebijakan swasembada beras dan impor beras. Keduanya menjadi menu kebijakan yang utama untuk memastikan masyarakat Indonesia cukup dan terjangkau dalam mengkonsumsi beras.

Kebijakan swasembada beras menjadi target "prestisius" namun justru jarang dapat tercapai secara konsisten. Selama tahun 1961 hingga tahun 2019, hanya pada tahun 1985-1986 dan 1994, Indonesia mampu mewujudkan swasembada beras. Capaian tersebut tidak terlepas dari Rezim Soeharto yang menerapkan "strategi kembar", yaitu stabilisasi harga beras pada jangka pendek dan target swasembada beras pada jangka panjang (Raditya, 2018). Di sisi lain, impor beras yang seringkali membuat gaduh, dilakukan Indonesia hampir setiap saat. Hal ini karena cadangan beras nasional melalui Bulog membutuhkan pasokan kontinu agar mampu dan efektif dalam menjalankan stabilitas harga beras dan sekaligus mendistribusikan beras sejahtera (rastra) kepada rumah tangga sasaran (RTS).

Gambar 2 menunjukkan perkembangan swasembada beras yang dihitung dengan pendekatan Self Sufficiency Ratio $(\mathrm{SSR})^{3}$ dan ketergantungan impor beras yang dikalkulasi dengan pendekatan Import Dependency Ratio (IDR) ${ }^{4}$. Sepanjang tahun 1961-2019, nilai SSR beras Indonesia mencapai lebih dari 90\%. Secara umum dapat dikatakan hampir sebagian besar kebutuhan beras di dalam negeri dipenuhi dari produksi domestik dan hanya sekitar $5 \%$ atau kurang dari $10 \%$ dari total produksi domestik yang berasal dari impor.

Formula $\mathrm{SSR}=$ Produksi/(Produksi+imporekspor) $\times 100$.

4 Formula IDR = Impor/(Produksi+impor-ekspor) $\mathrm{x}$ 100. 


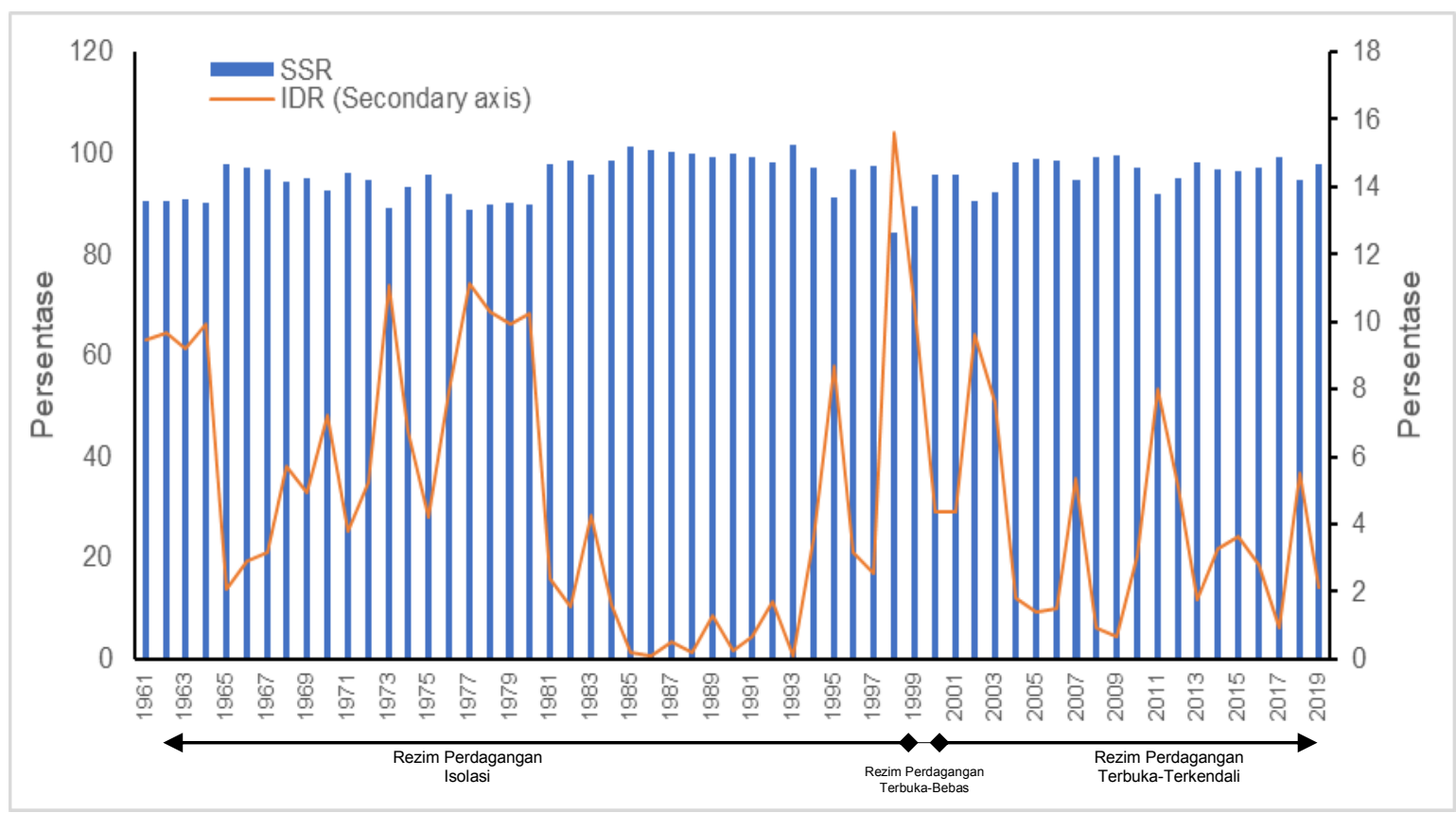

Gambar 2. Perkembangan SSR dan IDR Beras Indonesia Tahun 1961-2019

Sumber: PSD-USDA (2019)

Pada Gambar 2 juga dapat dilihat nilai IDR beras yang sangat berfluktuatif. Semakin besar nilai IDR beras maka ketergantungan pada impor juga semakin tinggi, begitu sebaliknya. Nilai IDR beras terendah terjadi sepanjang tahun 1984-1993 (rezim isolasi pasar), di mana angkanya tidak lebih dari $2 \%$. Hal ini terjadi karena insentif sangat besar diberikan oleh pemerintah untuk mendukung keberhasilan program swasembada beras. Pada sisi produksi muncul program penyuluhan berupa instruksi massal (inmas) dan bimbingan massal (bimas) untuk mendorong panca usahatani. Apalagi saat itu, sebelum lahirnya Undang-Undang No. 12 Tahun 1992 tentang Sistem Budidaya Tanaman, pemerintah dapat leluasa melakukan "berasisasi" di hampir seluruh wilayah Indonesia. Pada sisi bantuan pembiayaan dan permodalan dibentuk layanan berupa kredt usaha tani (KUT), kerja sama dengan koperasi unit desa (KUD), dan Bank Rakyat Indonesia (BRI). Selain itu, Bulog dibekali dana tak terbatas untuk menyerap beras petani dan bahkan outlet beras dari penjualan beras dari Bulog diperluas hingga menyasar pada pegawai negeri sipil.

IDR beras mencapai angka tertinggi pada tahun 1998, yaitu sekitar 
$15 \%$. Artinya, pada saat itu dari total kebutuhan beras di dalam negeri ternyata sekitar $15 \%$ berasal dari impor. Pada tahun 1998, Indonesia mengalami penurunan produktivitas padi yang signifikan akibat kekeringan sehingga terjadinya gagal panen (puso) di beberapa wilayah di Indonesia. Kondisi tersebut diperparah dengan krisis ekonomi yang menstimulasi inflasi hingga $57 \%$ sehingga menurunkan daya beli masyarakat. Melalui kesepakatan dengan IMF, pada tahun 1998, Indonesia harus meliberalisasi pasar berasnya, termasuk menghapus hak monopoli Bulog dalam importasi beras melalui Inpres No. 19 Tahun 1998 tentang Penetapan Harga Dasar Gabah.

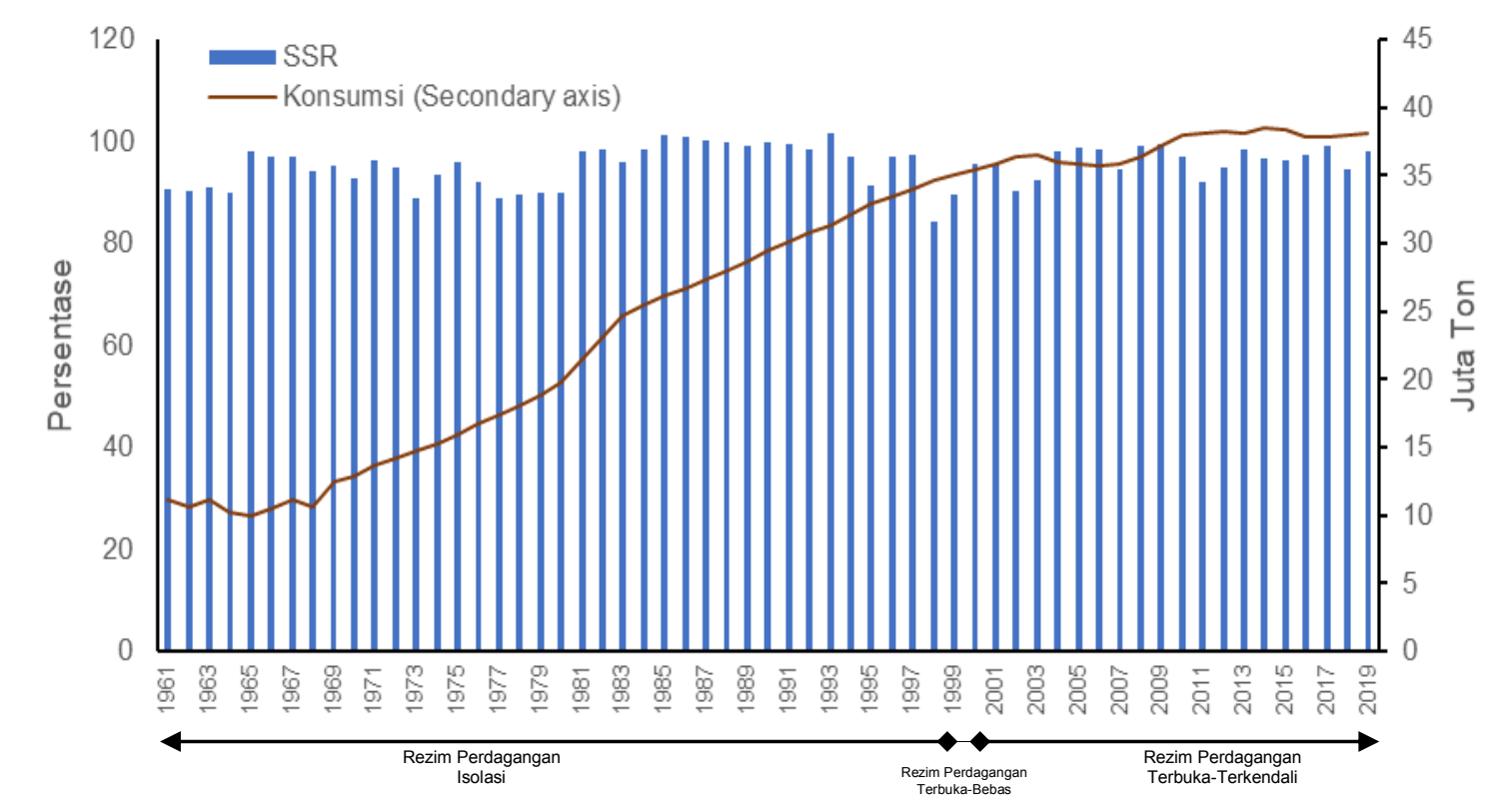

Gambar 3. SSR dan Konsumsi Beras Indonesia Tahun 1961-2019

Sumber: PSD-USDA (2019)

Bagaimana kaitan swasembada beras dengan konsumsi beras? Pada Gambar 3, total konsumsi beras Indonesia cenderung meningkat setiap tahunnya seiring dengan bertambahnya jumlah penduduk Indonesia. Namun menurut data BPS (2019), sebenarnya rata-rata konsumsi beras per kapitanya cenderung menurun $11,6 \%$ selama 10 tahun terakhir. Hal ini dapat disebabkan oleh perubahan preferensi masyarakat terhadap pola hidup sehat dan munculnya banyak pilihan sumber karbohidrat lainnya. Di sisi lain, angka 
SSR beras tidak meningkat secara signifikan. Beberapa peneliti berusaha menjelaskan hal itu karena produktivitas padi/beras Indonesia mengalami fenomena levelling off (kejenuhan) akibat penggunaan pupuk dan pestisida anorganik (kimiawi).
Bersama-sama dengan peningkatan laju alih fungsi lahan pertanian ke non pertanian dan adanya perubahan iklim global maka dikhawatirkan produksi beras nasional akan semakin menurun di masa mendatang.

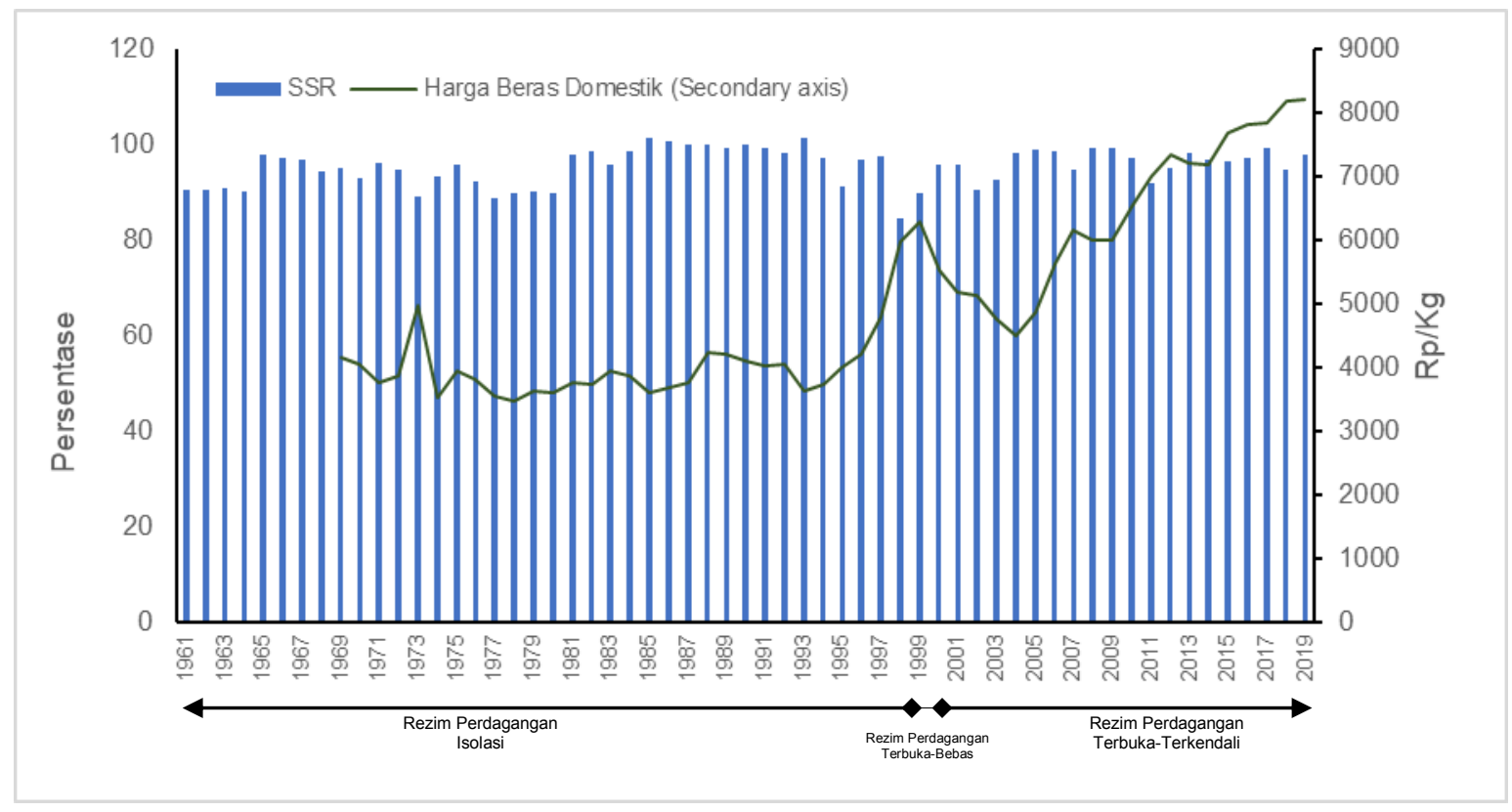

\section{Gambar 4. SSR dan Harga Beras Indonesia Tahun 1961-2016}

Sumber: PSD-USDA (2019)

Pada Gambar 4 disajikan perkembangan perbandingan antara perkembangan swasembada beras dengan harga beras domestik. Gambar tersebut menunjukkan bahwa pencapaian swasembada beras ternyata tidak serta menjamin bahwa harga beras domestik akan menjadi lebih stabil, bahkan cenderung meningkat. Harga beras Indonesia sejak tahun 1969-1996 cenderung stabil, yaitu di kisaran Rp 3.500-4.000 per kilogram. Namun memasuki tahun 1997-1999 terjadi pelonjakan harga yang cukup tajam hingga lebih dari Rp 6.000 per kilogram. Hal ini disebabkan turunnya produksi beras pada periode tersebut dan adanya krisis ekonomi yang juga ikut mendorong meningkatnya harga beras. 
Terlepas dari polemik apakah harga beras Indonesia lebih mahal atau lebih murah dari harga beras di negaranegara lain, menurut Moya, et al., (2016), yang perlu diperhatikan adalah bahwa biaya produksi beras Indonesia masih relatif lebih mahal dibandingkan negara-negara lainnya, di mana biaya tenaga kerja dan lahan mendominasi.

\section{Integrasi Pasar Beras}

Secara umum fase-fase kebijakan perdagangan beras beragam selama lebih dari 45 tahun terakhir, di mana dimulai dari (a) fase pertama disebut rezim perdagangan pasar isolasi yang terjadi pada tahun 1945an-1968 (Orde Lama) dan tahun 1969-1997 (Orde Baru), (b) fase kedua disebut rezim perdagangan pasar terbuka-bebas yang terjadi pada tahun 1998-1999, dan (c) fase ketiga tahun 2000sekarang yang disebut rezim perdagangan pasar terbuka-terkendali. Pada fase kedua dan ketiga tersebut, pasar beras Indonesia mulai bersentuhan dengan pasar beras Internasional setelah Indonesia menandatangi Lol dengan IMF pada tahun 1997/1998 (Pranolo, 2002; Arifin dalam Andriyanto, 2012).

Tabel 2. Hasil Uji Stasioner terhadap Variabel Harga Beras Indonesia dan Harga Beras Internasional

\begin{tabular}{|c|c|c|c|c|c|}
\hline Periode & $\begin{array}{c}\text { Rezim } \\
\text { Pemerintahan }\end{array}$ & Variabel & Probability & $\begin{array}{c}\text { Klasifikasi } \\
\text { Kestasioneran }\end{array}$ & $\begin{array}{c}\text { Rezim } \\
\text { Perdagangan }\end{array}$ \\
\hline $\begin{array}{l}1998- \\
1999\end{array}$ & Orde Baru & $\begin{array}{l}\text { Harga Beras } \\
\text { Indonesia } \\
\text { Harga Beras } \\
\text { Thailand }\end{array}$ & $\begin{array}{l}0,01 \\
0,004\end{array}$ & $\begin{array}{l}\text { Stasioner first } \\
\text { difference } \\
\text { Stasioner first } \\
\text { difference }\end{array}$ & Terbuka-bebas \\
\hline $\begin{array}{l}2000- \\
2007\end{array}$ & Reformasi & $\begin{array}{l}\text { Harga Beras } \\
\text { Indonesia } \\
\text { Harga Beras } \\
\text { Thailand }\end{array}$ & $\begin{array}{l}0,00 \\
0,00\end{array}$ & $\begin{array}{l}\text { Stasioner first } \\
\text { difference } \\
\text { Stasioner first } \\
\text { difference }\end{array}$ & $\begin{array}{l}\text { Terbuka- } \\
\text { terkendali }\end{array}$ \\
\hline $\begin{array}{l}2008- \\
2017\end{array}$ & Reformasi & $\begin{array}{l}\text { Harga Beras } \\
\text { Indonesia } \\
\text { Harga Beras } \\
\text { Thailand }\end{array}$ & $\begin{array}{l}0,00 \\
0,00\end{array}$ & $\begin{array}{l}\text { Stasioner first } \\
\text { difference } \\
\text { Stasioner first } \\
\text { difference }\end{array}$ & $\begin{array}{l}\text { Terbuka- } \\
\text { terkendali }\end{array}$ \\
\hline $\begin{array}{l}2000- \\
2017\end{array}$ & Reformasi & $\begin{array}{l}\text { Harga Beras } \\
\text { Indonesia } \\
\text { Harga Beras } \\
\text { Thailand }\end{array}$ & 0,00 & $\begin{array}{l}\text { Stasioner first } \\
\text { difference } \\
\text { Stasioner first } \\
\text { difference }\end{array}$ & $\begin{array}{l}\text { Terbuka- } \\
\text { terkendali }\end{array}$ \\
\hline
\end{tabular}

Sumber: Hasil olah data dari berbagai sumber (2018)

Tabel 2 menyajikan hasil uji akar unit dari variabel yang digunakan dalam penelitian ini serta klasifikasi kestasioneran data time series. Hasil uji stasioner menunjukkan pada setiap periode, seluruh variabel tersebut 
terintegrasi pada derajat yang sama (first difference) dengan tingkat kepercayaan 1\%, 5\%, dan 10\%. Periodesasi analisis sebelum tahun 1998 (rezim perdagangan isolasi pasar) tidak dielaborasi lebih lanjut karena Indonesia belum membuka diri terhadap pasar beras internasional sehingga diasumsikan integrasi harga beras belum terjadi dan tidak menjadi topik penelitian ini.

Tabel 3 menyajikan hasil uji kointegrasi Johansen. Pada periode tahun 1998-1999, 2000-2007, dan tahun 2008-2017, antara harga beras domestik dengan internasional, terdapat masing-masing 1 kointegrasi, yaitu pada rank = 0 (none). Artinya, pada pasar-pasar tersebut terdapat hubungan atau keseimbangan jangka panjang, tetapi dalam jangka pendek mungkin saja terjadi ketidakseimbangan. Setiap ada penyimpangan yang mengarah keluar dari keseimbangan maka mekanisme pasar akan mengoreksinya lagi. Proses ini terjadi secara otomatis tanpa adanya campur tangan pemerintah atau pihak lain (Sugiyanto \& Hadiwigeno, 2018). Meskipun rezimnya terbuka-terkendali, kointegrasi masih terjadi pasca krisis pangan dunia. Sedangkan apabila dilakukan analisis periode secara keseluruhan pada era perdagangan terbuka-terkendali pada tahun 2000-2017 ternyata tidak terdapat kointegrasi atau dapat dikatakan pada pasar tersebut tidak terdapat hubungan atau keseimbangan jangka panjang.

Tabel 3. Hasil Uji Johansen Maximum Likelihood untuk Pasar Beras Indonesia dengan Pasar Beras Internasional

\begin{tabular}{|c|c|c|c|c|c|c|}
\hline Periode & $\begin{array}{c}\text { Rezim } \\
\text { Perdagangan }\end{array}$ & Market Pair & Hipotesis & Eigenvalue & $\begin{array}{c}\text { Trace } \\
\text { Statistic }\end{array}$ & $\begin{array}{c}5 \text { Percent } \\
\text { Critical } \\
\text { Value }\end{array}$ \\
\hline \multirow{2}{*}{$\begin{array}{l}1998- \\
1999\end{array}$} & \multirow{2}{*}{$\begin{array}{l}\text { Terbuka- } \\
\text { bebas }\end{array}$} & \multirow{2}{*}{$\begin{array}{l}\text { Indonesia- } \\
\text { Internasional }\end{array}$} & None* & 0,52 & 19,57 & 15,49 \\
\hline & & & At most 1 & 0,15 & 3,51 & 3,84 \\
\hline \multirow{2}{*}{$\begin{array}{l}2000- \\
2007\end{array}$} & \multirow{2}{*}{$\begin{array}{l}\text { Terbuka- } \\
\text { terkendali }\end{array}$} & \multirow{2}{*}{$\begin{array}{l}\text { Indonesia- } \\
\text { Internasional }\end{array}$} & None* & 6,39 & 7,09 & 15,49 \\
\hline & & & At most 1 & 0,70 & 0,70 & 3,84 \\
\hline \multirow{2}{*}{$\begin{array}{l}2008- \\
2017\end{array}$} & \multirow{2}{*}{$\begin{array}{l}\text { Terbuka- } \\
\text { terkendali }\end{array}$} & \multirow{2}{*}{$\begin{array}{l}\text { Indonesia- } \\
\text { Internasional }\end{array}$} & None* & 0,13 & 17,72 & 15,49 \\
\hline & & & At most 1 & 0,03 & 3,17 & 3,84 \\
\hline \multirow{2}{*}{$\begin{array}{l}2000- \\
2017\end{array}$} & \multirow{2}{*}{$\begin{array}{l}\text { Terbuka- } \\
\text { terkendali }\end{array}$} & \multirow{2}{*}{$\begin{array}{l}\text { Indonesia- } \\
\text { Internasional }\end{array}$} & None & 0,03 & 7,71 & 15,49 \\
\hline & & & At most 1 & 0,00 & 0,95 & 3,84 \\
\hline
\end{tabular}


Temuan ini sejalan dengan penelitian Sofiah (2016), namun berbeda dengan penelitian Cahyaningsih, et al. (2012). Perbedaan tersebut dapat terjadi karena periode analisis dan jenis beras yang digunakan juga berbeda-beda. Penelitan Sofiah (2016) menggunakan data bulanan tahun 2013-2016 dengan kualitas beras rendah, sedangkan penelitian Cahyaningsih, et al. (2012) menggunakan data bulanan tahun 2001-2011 dengan kualitas beras premium (broken 15\%).

Untuk mengetahui arah kointegrasi antara harga beras Indonesia dan beras internasional digunakan uji kausalitas Granger dengan hasil yang dilihat pada Tabel 4 . Berdasarkan hasil uji maka pada rezim perdagangan pasar terbuka-bebas periode tahun 1998-1999 menunjukkan harga beras Indonesia dan harga beras internasional terdapat kausalitas satu arah, di mana harga beras di Indonesia dipengaruhi oleh harga beras internasional $(\alpha<0,05)$. Pada periode rezim perdagangan pasar terbukaterkendali, baik pada tahun 2000-2007 dan 2008-2017, tidak terdapat kausalitas atau hubungan saling memengaruhi antara harga beras di Indonesia dengan harga beras internasional.

Tabel 4. Hasil Uji Granger Causality untuk Harga Beras Indonesia dengan Harga Beras Internasional

\begin{tabular}{lllll}
\hline \multirow{2}{*}{ Periode } & $\begin{array}{c}\text { Rezim } \\
\text { Perdagangan }\end{array}$ & Hipotesis & \multirow{2}{*}{ F-Statistic } & \multirow{2}{*}{ Probability } \\
\hline $1998-$ & Terbuka- & THAI does not Granger Cause INDO & 0,40 & 0,54 \\
1999 & bebas & INDO does not Granger Cause THAI & 12,24 & $0,00^{*}$ \\
\hline $2000-$ & Terbuka- & THAI does not Granger Cause INDO & 1,20 & 0,31 \\
2007 & terkendali & INDO does not Granger Cause THAI & 1,40 & 0,25 \\
\hline $2008-$ & Terbuka- & THAI does not Granger Cause INDO & 0,96 & 0,41 \\
2017 & terkendali & INDO does not Granger Cause THAI & 0,37 & 0,77 \\
\hline $2000-$ & Terbuka- & THAI does not Granger Cause INDO & 1,41 & 0,24 \\
2017 & terkendali & INDO does not Granger Cause THAI & 0,85 & 0,47 \\
\hline
\end{tabular}

Sumber : Hasil olah data dari berbagai sumber (2018).

Keterangan : * menunjukkan signifikansi pada $\alpha=5 \%$

Demikian juga pada periode tahun 2000-2017 atau periode pasca rezim perdagangan pasar terbuka-terkendali, tidak terdapat hubungan saling memengaruhi satu sama lain. Hasil tersebut mengindikasikan bahwa pada rezim perdagangan pasar terbukabebas yang ditandai dengan penghapusan peran Bulog dalam distribusi dan impor serta pengenaan 
tarif impor beras $0 \%$ pada tahun 1999 , menjadikan pasar beras internasional memengaruhi perilaku fluktuasi harga beras domestik namun tidak berlaku sebaliknya.

Rangkaian hasil tersebut juga diverifikasi dengan menggunakan pendekatan lain, yaitu IMC (Tabel 5). Pada kolom IMC memberikan informasi tambahan tentang seberapa kuat kointegrasi terjadi pada masing-masing rezim perdagangan dalam jangka pendek. Apabila dibandingkan antara kedua rezim perdagangan maka rezim perdagangan terbuka-bebas relatif lebih terintegrasi dibandingkan dengan rezim perdagangan terbuka-terkendali, baik pada tahun 2000-2007 dan tahun 2008-2016. Hal itu ditunjukkan dengan nilai IMC yang relatif lebih rendah dibandingkan dengan rezim perdagangan lainnya. Atau dengan kata lain secara relatif, pada saat diberlakukan rezim perdagangan terbuka-bebas, integrasi masih terjadi antara harga beras Indonesia dengan harga internasional. Hasil dengan pendekatan IMC tersebut secara umum masih konsisten dengan hasil analisis dengan pendekatan ECM sebelumnya.

Tabel 5. Integrasi Harga Beras Indonesia dengan Harga Beras Internasional Melalui Pendekatan Index of Market Connection

\begin{tabular}{ccccccccccc}
\hline \multirow{2}{*}{ Periode } & $\begin{array}{c}\text { Rezim } \\
\text { Perdagangan }\end{array}$ & Market Pair & $\boldsymbol{\beta}_{0}$ & $\boldsymbol{\beta}_{1}$ & $\boldsymbol{\beta}_{2}$ & $\boldsymbol{\beta}_{3}$ & $\mathbf{R}^{2}$ & $\begin{array}{c}\text { Durbin } \\
\text { Watson }\end{array}$ & IMC \\
\hline $1998-1999$ & Terbuka-bebas & Indonesia-Internasional & $-2,41^{* *}$ & $1,03^{*}$ & $1,09^{*}$ & $0,39^{* *}$ & 0,96 & 2,03 & 2,62 \\
$2000-2007$ & Terbuka-terkendali & Indonesia-Internasional & $-0,04$ & $0,98^{*}$ & 0,05 & 0,01 & 0,99 & 1,89 & 73,20 \\
$2008-2016$ & Terbuka-terkendali & Indonesia-Internasional & $0,32^{* * * *}$ & $0,93^{*}$ & 0,01 & 0,02 & 0,93 & 2,03 & 37,85 \\
\hline
\end{tabular}

Sumber : dari berbagai sumber dan data diolah dengan SAS 9.2.

Keterangan : ${ }^{*},{ }^{* *},{ }^{* * * *},{ }^{* * *}$ menunjukkan signifikansi masing-masing $\alpha=1 \%, \alpha=5 \%, \alpha=15 \%$, dan $\alpha=20 \%$. Untuk persamaan pada rezim reformasi ditambahkan variabel dummy krisis pangan (2007/2008). Nilai dugaan parameter tidak ditampilkan pada tabel, kecuali dugaan parameter variabel harga.

Pada perspektif regional, kointegrasi harga beras Jakarta kointegrasi harga beras nasional (sebagai acuan) dengan harga beras di tersebut dilihat lebih dalam dengan kota-kota besar di Indonesia. Secara melihat apakah kointegrasi tersebut umum, hasilnya menunjukkan bahwa juga terjadi antar harga beras di harga beras di DKI Jakarta dengan beberapa kota besar di Indonesia dalam jangka pendek. Pada Tabel 6 menyajikan bagaimana situasi kota-kota besar terintegrasi dengan kekuatan yang berbeda-beda. Harga beras di DKI Jakarta dengan di 
Bandung integrasi relatif lebih kuat dibandingkan dengan kota lainnya.

Hasil penelitian ini relatif sejalan dengan hasil penelitian dari Hidayanto, et al. (2014), di mana pasar beras tingkat retail pada 26 provinsi di Indonesia tidak sepenuhnya terintegrasi dengan pasar beras grosir di PIBC, Jakarta. Sedangkan menurut Alexander \& Wyeth (1994), DKI Jakarta merupakan daerah defisit beras dan sekaligus sentra permintaan beras utama di Indonesia yang dipengaruhi oleh variasi harga beras dari wilayah lainnya, termasuk dari Bandung, Medan, Surabaya, dan Makassar. Ditambahkan oleh Sugiyanto \& Hadiwigeno (2018), dengan menggunakan data pasar beras dari sisi produsen, bahwa pasar domestik menunjukkan keterkaitan meskipun tidak selamanya simetris (dua arah).

Integrasi pasar beras di berbagai wilayah di Indonesia tersebut dapat terkaji karena dipengaruhi oleh banyak faktor. Misalnya menurut Cahyaningsih, et al. (2012), hal itu dipengaruhi oleh kondisi spesifik daerah (terpencil) dan sistem konektivitas (transportasi) yang kurang mendukung sehingga meningkatkan biaya perdagangan. Faktor lainnya yang ikut memengaruhi integrasi pasar beras antarwilayah, antara lain pendapatan per kapita (Ismet, et al., 1998), aktivitas pembelian (pengadaan) beras petani oleh Perum Bulog, dan penyaluran beras untuk keluarga miskin (raskin) (Hidayanto, et al., 2014).

Tabel 6. Integrasi Harga Beras di Jakarta dengan Harga Beras di Beberapa Kota Besar Indonesia Tahun 2011-2017

\begin{tabular}{lllllllll}
\hline No. & Market Pair & $\boldsymbol{\beta}_{0}$ & $\boldsymbol{\beta}_{\mathbf{1}}$ & $\boldsymbol{\beta}_{\mathbf{2}^{\mathbf{a}}}$ & $\boldsymbol{\beta}_{\mathbf{3}}$ & $\mathbf{R}^{\mathbf{2}}$ & $\begin{array}{l}\text { Durbin } \\
\text { Watson }\end{array}$ & IMC \\
\hline 1. & Jakarta-Medan & $1,03^{* *}$ & $0,70^{*}$ & 0,02 & $0,19^{* *}$ & 0,86 & 1,95 & 3,73 \\
2. & Jakarta-Bandung & 0,43 & $0,49^{*}$ & $1,11^{*}$ & $0,46^{*}$ & 0,96 & 1,54 & 1,08 \\
3. & Jakarta-Semarang & 0,78 & $0,70^{*}$ & $0,51^{*}$ & $0,21^{* *}$ & 0,92 & 1,46 & 3,33 \\
4. & Jakarta-Yogyakarta & 0,17 & $0,91^{*}$ & $0,22^{* *}$ & 0,07 & 0,95 & 1,84 & 12,90 \\
5. & Jakarta-Surabaya & 0,25 & $0,91^{*}$ & 0,04 & 0,06 & 0,95 & 1,80 & 15,04 \\
6. & Jakarta-Denpasar & $-0,02$ & $0,79^{*}$ & $0,48^{*}$ & $0,21^{* *}$ & 0,95 & 1,59 & 3,85 \\
7. & Jakarta-Makassar & 0,08 & $0,78^{*}$ & $0,43^{*}$ & $0,20^{* *}$ & 0,93 & 1,65 & 3,84 \\
\hline
\end{tabular}

Sumber : dari berbagai sumber dan data bulanan diolah dengan SAS 9,2

Keterangan : * , **, menunjukkan signifikansi masing-masing $\alpha=1 \%$ dan $\alpha=5 \%$.

a menunjukkan integrasi dalam jangka panjang. 
Integrasi Harga Beras Indonesia dan Dampaknya terhadap Swasembada Beras dan Kesejahteraan Pelaku Ekonomi

Kekhawatiran banyak pihak bahwa keterbukaan pasar beras nasional secara bebas akan merugikan pelaku ekonomi di dalam negeri, termasuk pula upaya swasembada pangan (beras), menjadi pertimbangan utama mengapa tarif spesifik mulai diberlakukan kembali pasca tahun 1999. Apabila dilihat dari Tabel 7 pada kolom level swasembada beras dan kesejahteraan pelaku ekonomi maka pada rezim perdagangan terbukabebas, capaian swasembada beras adalah yang terendah dibandingkan rezim perdagangan terbuka-terkendali. Hal ini dapat terjadi karena harga beras Indonesia lebih kompetitif karena tidak adanya tarif. Penurunan harga beras tersebut menjadi sinyal negatif bagi produsen beras untuk berproduksi, namun justru menjadi sinyal positif bagi konsumen dalam mengkonsumsi beras. Menurut Ismet, et al. (1998) setelah era swasembada beras pada tahun 1984, intervensi pemerintah mulai banyak berkurang (dibandingkan rezim perdagangan isolasi) sehingga memungkinkan sektor private merespon perubahan harga tersebut dengan lebih tepat.

Tabel 7. Integrasi Harga Beras Indonesia dan Dampaknya terhadap Swasembada Beras dan Kesejahteraan Pelaku Ekonomi Beras

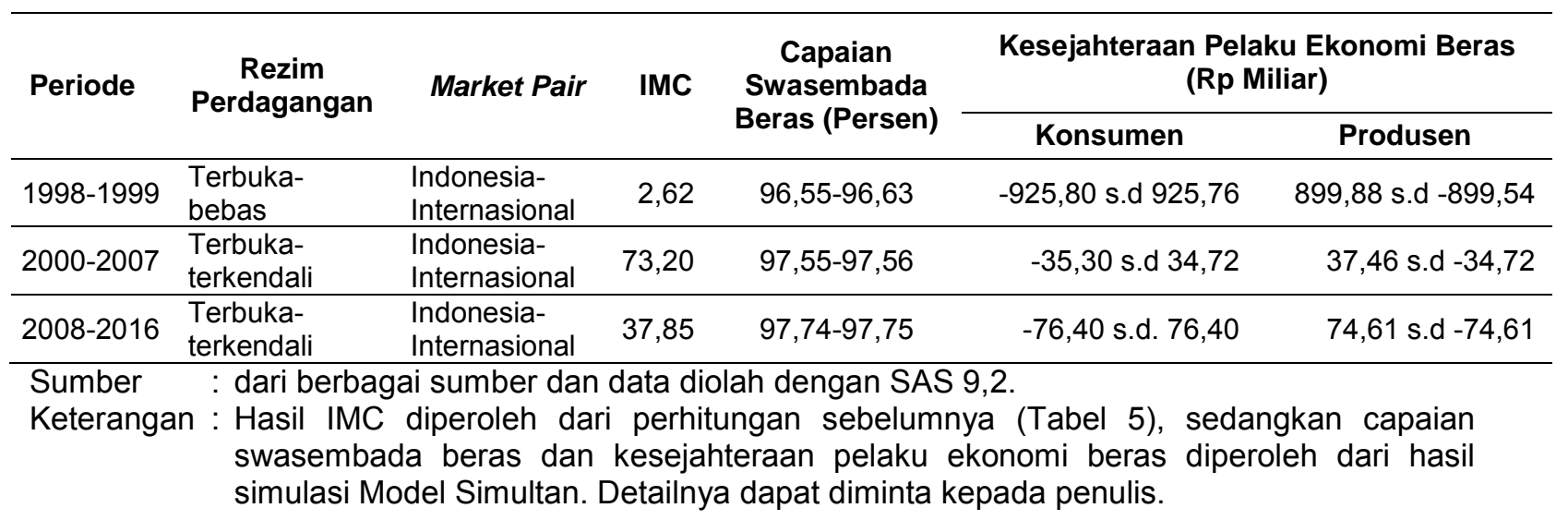

Berdasarkan kondisi tersebut, produsen beras, seperti subsidi input tidak heran apabila intervensi hingga harga. Namun demikian, pemerintah lebih banyak menyasar pada upaya melindungi petani atau paradigma bahwa mengkondisikan harga beras yang tinggi adalah baik 
untuk kepentingan produsen perlu dipertimbangkan karena pada akhirnya konsumen akan dirugikan. Pada dasarnya, Indonesia merupakan negara net importir beras, di mana ketika pemerintah berusaha mendukung keberlanjutan usaha dan kesejahteraan petani dengan mengintervensi pasar guna meningkatkan harga beras di tingkat petani, hal itu justru dapat berbalik merugikan mereka karena petani produsen juga mengkonsumsi beras. Simatupang (1999) dalam Irawan, et al. (2007) mengingatkan adanya transmisi harga yang asimetris, yaitu dicirikan saat penurunan harga ditransmisikan dengan cepat dan sempurna kepada petani, namun kenaikan harga ditransmisikan dengan lambat dan tidak sempurna.

Selain itu, penurunan level swasembada beras pada saat rezim perdagangan terbuka-bebas tersebut dapat dimaknai sebagai konsekuensi logis dari adanya penyesuaian terhadap meningkatnya kompetisi dan efisiensi dalam menggunakan sumber daya. Adanya kointegrasi antara harga beras domestik dengan harga beras internasional dengan kausalitas searah menunjukkan bahwa harga beras domestik berubah mengikuti kondisi harga beras internasional yang relatif lebih kompetitif pada rezim perdagangan terbuka-bebas. Rezim tersebut membuka kesempatan yang lebih luas terjadinya realokasi sumber daya, mengingat harga beras domestik cenderung lebih tinggi dibandingkan harga beras internasional.

Apabila dilihat dampaknya terhadap kesejahteraan pelaku ekonomi maka produsen dan konsumen akan menikmati benefit dengan rentang yang lebih besar pada rezim perdagangan terbuka bebas dibandingkan rezim perdagangan terbuka terkendali. Kondisi ini memberikan penegasan tentang peran perdagangan bebas yang sejatinya dapat menstimulasi realokasi sumber daya sehingga kegiatan ekonomi menjadi lebih efisien, baik bagi produsen maupun konsumen.

\section{KESIMPULAN DAN REKOMENDASI KEBIJAKAN}

Pada rezim perdagangan terbukabebas (1998-1999), harga beras Indonesia terintegrasi dengan harga beras internasional dalam jangka panjang. Pada kondisi tersebut, posisi Indonesia adalah sebagai negara terbuka dengan volume impor lebih dari 6 juta ton atau sekitar $50 \%$ dari pasar impor beras. Indikasi integrasi juga 
terjadi pada rezim perdagangan terbuka-terkendali pasca krisis pangan tahun 2008.

Selanjutnya, integrasi pada level regional antara harga beras di Kota Jakarta dengan beberapa kota besar lainnya terjadi sangat lemah pada rezim perdagangan terbuka-terkendali. Berbagai faktor diduga menyebabkan hal ini terjadi, salah satunya karena distribusi beras yang tidak efisien.

Evaluasi terhadap kebijakan retreat to autarky dengan menerapkan program swasembada beras untuk meningkatkan kesejahteraan produsen yang dilakukan Indonesia selama ini perlu dipertimbangkan kembali. Melalui transmisi harga beras yang terbentuk antara harga beras domestik dengan harga beras dunia menunjukkan adanya trade off antara meningkatkan kesejahteraan produsen, baik saat rezim perdagangan terbuka-bebas maupun rezim perdagangan terbukaterkendali. Meskipun pada rezim perdagangan terbuka-bebas level swasembada beras mengalami penurunan, namun tingkat kesejahteraan produsen beras dan konsumen beras berpotensi mencapai benefit yang relatif lebih besar dibandingkan rezim perdagangan terbuka-terkendali. Dengan demikian, kebijakan perdagangan bebas beras bukan hal yang harus dihindari, tetapi dapat menjadi opsi kebijakan untuk memenuhi kebutuhan beras domestik dan menstabilkan harganya.

\section{UCAPAN TERIMA KASIH}

Kami sampaikan terima kasih khususnya kepada Dr. Indra Pahlevi selaku Kepala Pusat Penelitian Badan Keahlian DPR RI dan juga semua pihak yang telah membantu di dalam proses pengumpulan data, penyusunan naskah hingga terbitnya jurnal ini.

\section{DAFTAR PUSTAKA}

Agung, I Dewa Gede \& Daryanto, J. (2017). Analisis Integrasi Pasar Beras di Provinsi Bali. E-Jurnal Agribisnis dan Agrowisata, Vol. 6, No. 1, pp. 115-121.

Akintunde, O.K., Yusuf, S.A., Bolarinwa, A.O., \& Ibe, R.B. (2012). Price Formation and Transmission of Staple Food Stuffs in Osun State, Nigeria. Journal of Agricultural and Biological Science, Vol. 7, No. 9, pp. 699-708.

Alexander, C., \& Wyeth, J. (1994). Cointegration and Market Integration: An Application to The Indonesian Rice Market. The Journal of Development Studies, Vol. 30, No. 2, pp. 303-328.

Andriyanto, T. (2012). Pengaruh Letter of Intent (Lol) IMF terhadap Pelemahan Ketahanan Pangan Beras Indonesia 1995-2009. Skripsi. Depok: Fakultas IImu Sosial dan Politik, Universitas Indonesia.

Arifin, B. (2007). Diagnosis ekonomi politik pangan dan pertanian. Jakarta: PT Raja Grafindo Persada. 
Arnanto, Hartoyo, S., \& Rindayati, W. (2014). Analisis Integrasi Pasar Spasial Komoditi Pangan Antar Provinsi di Indonesia. Jurnal Ekonomi dan Kebijakan Pembanguan, Vol. 3, No. 2, hal. 136157

Azahari, D.H., \& Hadiutomo, K. (2014). Analisis Keunggulan Komparatif Beras Indonesia. Analisis Kebijakan Pertanian, Vol. 11, No. 1, hal. 61-73.

BPS. (2019). Rata-Rata Konsumsi per Kapita Seminggu Beberapa Macam Bahan Makanan Penting, 2007-2018. https://www.bps.go.id/statictable/201 4/09/08/950/rata-rata-konsumsi-perkapita-seminggu-beberapa-macambahan-makanan-penting-20072018.html. Diakses 8 Juli 2019.

Bustaman, A.D. (2003). Analisis Integrasi Pasar Beras di Indonesia. Skripsi. Institut Pertanian Bogor, Bogor.

Cahyaningsih, E., Nurmalina, R., \& Maulana, A. (2012). Integrasi Spasial dan Vertikal Pasar Beras di Indonesia. Pangan, Vol. 21, No. 4, hal. 317-332.

Carolina, Mulatsih, S., \& Anggraeni, L. (2016). Analisis Volatilitas Harga dan Integrasi Pasar Kedelai Indonesia dengan Pasar Kedelai Dunia. Jurnal Agro Ekonomi, Vol. 34 No. 1, hal. 4766.

Chiang, A.C. (1984). Fundamental methods of mathematical economics. $3^{\text {rd }}$ Ed. New York: McGraw-Hill, Inc.

Dawe, D. (2008). Can Indonesia Trust the World Rice Market? Bulletin of Indonesian Economic Studies, Vol. 44 , No. 1 , pp. $115-132$.

FAO. (2003). Trade Reform and Food Security, Conceptualizing the Linkages. Rome: Food and Agriculture Organization.

Farid, M., Wicaksena, B., Nuryati, Y., Prabowo, D.W., Yulianti, A., \& Haryana, A. (2014). Analisis Kebijakan Harga pada Komoditas Pertanian. Jakarta: Pusat Kebijakan
Perdagangan Dalam Negeri, Badan Pengkajian dan Pengembangan Kebijakan Perdagangan, Kementerian Perdagangan

Hidayanto, M.W., Anggraeni, L., \& Hakim, D.B. (2014). Faktor Penentu Integrasi Pasar Beras di Indonesia. Pangan, Vol. 23, No. 1, hal. 1-16.

Idris, M. (2017). RI Produsen Beras No. 3 Dunia Tapi Harganya Mahal, Kok Bisa?

(https://finance.detik.com/beritaekonomi-bisnis/d-3534836/riprodusen-beras-no3-dunia-tapiharganya-mahal-kok-bisa, diakses 07 Maret 2018).

Irawan, B., Tarigan, H., Wiryono, B., Hestina, J., \& Ashar. (2007). Kinerja dan Prospek Pembangunan Hortikultura. Prosiding: Kinerja dan Prospek Pembangunan Pertanian Indonesia. Pusat Analisis Sosial Ekonomi dan Kebijakan Pertanian Bogor, hal. 66-80.

Ismet, M., Barkley, A.P., \& Llewelyn, R.V. (1998). Government Intervention and Market Integration in Indonesian Rice Markets. Agricultural Economics, Vol. 19, No. 3, pp. 283-295.

Keputusan Menteri Keuangan Nomor 568/KMK.01/1999 tentang Penetapan Tarif Bea Masuk Atas Impor Beras dan Gula. 1999. Jakarta.

Kustiari, R., \& Suhaeti, R.N. (1998). Rice Market Integration in Indonesia: A Cointegration Analysis. Jurnal Agro Ekonomi, Vol. 17, No. 1, pp. 1-12.

Kusumah, F.P. (2019). Ekonomi Politik dalam Kebijakan Impor Beras: Membaca Arah Kebijakan Pemerintah 2014-2019. POLITIKA: Jurnal IImu Politik, Vol. 10, No. 2, hal. 137-162.

Kusumaningsih, A., Jamhari, \& Darwanto, D.H. (2016). Analysis of Rice Price Trend and Vertical Integration of Rice Market in Indonesia. IImu Pertanian 
(Agricultural Science), Vol. 1, No. 2, pp. 074-079.

Layade, A.A., \& Adeoye, I.B. (2014). Analysis of Price and Market Integration for Onion in Rural-Urban Markets of Oyo State, Nigeria. International Journal of Economics, Finance and Management, Vol. 3, No. 5 , pp. $238-243$.

Makbul, Y., \& Ratnaningtyas, S. (2017). Analysis of the Integration of Rice and Paddy Prices in Indonesia Using a Vector Error Correction Model. International Journal of Applied Business and Economic Research, Vol. 15, No.10, pp. 209-225.

Marks, D. (2010). Unity or Diversity? On the Integration and Efficiency of Rice Markets in Indonesia, c.1920-2006. Explorations in Economic History 47, pp. 310-324.

Moya, P.F., Bordey, F.H., Beltran, J.C., Manalili, R.G., Launio, C.C., Mataia, A.B., Litonjua, A.C., \& Dawe, D.C. (2016). In Bordey F.H, Moya P.F, Beltran J.C., and Dawe D.C. (Eds.). Competitiveness of Philippine Rice in Asia. Science City of Muñoz: Philippine Rice Research Institute and Manila, pp. 97-117.

OECD. (2013). OECD-FAO Agricultural Outlook 2013-2022. Paris: OECD Publishing

(http://dx.doi.org/10.1787/agr_outlook -2013-en).

Peraturan Menteri Keuangan Nomor 6/PMK.010/2017 tentang Penetapan Sistem Klasifikasi Barang dan Pembebanan Tarif Bea Masuk Atas Barang Impor. 2017. Jakarta.

Pranolo, T. (2002). Lol-IMF dan Implikasinya terhadap Peranan Bulog. Dalam M.H. Sawit, Tito P., Agus S., Bambang D., dan Sapuan (Eds.). Bulog: Pergulatan dalam Pemantapan Peranan dan Penyesuaian Kelembagaan, Kumpulan Naskah Dalam Rangka Menyambut 35 Tahun Bulog (hal.
417-422). Bogor: Institut Petanian Bogor Press.

Raditya, I.N. (2018). Swasembada Beras Ala Soeharto: Rapuh dan Cuma Fatamorgana.

https://tirto.id/swasembada-berasala-soeharto-rapuh-dan-cuma-

fatamorgana-c2eV, diakses 27 Juli 2019.

Ravallion, M. (1986). Testing Market Integration. American Agricultural Economics Association. 68, pp. 102109.

Sari, D.L. (2010). Analisis Spread Harga Gabah dan Beras, serta Integrasi Pasar dan Komoditas. Tesis. Institut Pertanian Bogor, Bogor.

Simatupang, P. (1999). Industrialisasi Pertanian sebagai Strategi Agribisnis dan Pembangunan Pertanian dalam Era Globalisasi. Dalam Dinamika Inovasi Ekonomi dan Kelembagaan Pertanian. Buku-2. Pusat Penelitian Sosial Ekonomi Pertanian. Bogor

Sofiah, A. (2016). Asimetri Harga Beras di Pasar Internasional dan Indonesia. Skripsi. Fakultas Ekonomi dan Manajemen, Institut Pertanian Bogor, Bogor.

Sugiyanto, C., \& Hadiwigeno, S. (2018). Integrasi Pasar Beras Indonesia dengan Pasar Beras Internasional. Jurnal Ekonomi dan Kebijakan Pembangunan, Vol. 1, No. 2, hal. 79-103.

Varela, G., Carroll, E. A., \& lacovone, L. (2012). Determinants of Market Integration and Price Transmission in Indonesia. Policy Research Working Paper 6098, The World Bank East Asia and Pacific Region.

Widadie, F., \& Sutanto, A. (2012). Model Ekonomi Perberasan: Analisis Integrasi Pasar dan Simulasi Kebijakan Harga. SEPA, Vol. 8 No. 2, hal. 51-182. 
46 | Buletin IImiah Litbang Perdagangan, VOL.14 NO.1, JULI 2020 